\title{
Utilization of Blogging Platforms and Acquisition of Entrepreneurial Skills for Self-Reliance Among Educational Technology Students in University of Calabar
}

\author{
Idongesit N. Udosen ${ }^{1} \&$ Beatrice E. Upula ${ }^{1}$ \\ ${ }^{1}$ Department of Educational Technology and Library Science, Faculty of Education, University of Uyo, Uyo, \\ Akwa Ibom State \\ Correspondence: Udosen, I. N., Department of Educational Technology and Library Science, Faculty of Education, \\ University of Uyo, Uyo, Akwa Ibom State. E-mail: idongesitudosen.lect@uniuyo.edu.ng
}

Received: December 27, 2018

Accepted: January 8, $2019 \quad$ Online Published: May 30, 2019

doi:10.5539/mas.v13n6p60

URL: https://doi.org/10.5539/mas.v13n6p60

\begin{abstract}
In this rapidly changing world, the quest for self-reliance has always been the desire of many nations especially in the present face of global economic challenge. This study centres on using blogging platforms for acquiring Entreprneurial skills for Self-reliance among Educational Technology Students in University of Calabar. The study utilized the descriptive survey design. Three research questions were raised and three research hypotheses were stated to guide the study. The population comprised all the 39 final year educational technology students from university of calabar. Thirty-nine final year Educational Technology students were purposively adopted as sample size for the study. Linear regression was used to test the hypotheses at 0.05 level of significance. The model summary table was used to answer research questions. The instrument for data collection was the utilization of blogging platforms for acquiring entrepreneurial skills for self-reliance questionnaire (UBPFESRQ). The instrument was face validated with a reliability coefficient of .80 using Chronbach Alpha Statistics. It was found that the Use of blogger, wordpress and steemit had no significant relationship with acquisition of entrepreneurial skills for self-reliance among educational technology students in University of Calabar. Some recommendations were made to include that emphasis should be laid on entrepreneurial skills and educational technology tools such as design, production and modernization of indigenous resources among students through practices and innovations for achieving self-reliant generation.
\end{abstract}

Keywords: blogging, self-reliance, entrepreneurship, educational technology, regression, steemit

\section{Introduction}

\subsection{Background Information}

Information, Communication Technology (ICT) has permeated every aspect of life from technology to business. The application of Information Communication Technology can enhance entrepreneurial competiveness as well as provide genuine benefits for students upon graduation. ICT tools as seen by Ayo (2001) is the use of computer system and telecommunication equipment in information processing. ICT utilization is the presentation and distribution of instructional content through web environment (Yusuf, 2005). ICT has the potential to accelerate, enrich and deepen student's skills as well as relate school experiences to work practice (Ololube, 2006).

Educational Technology is an aspect of the Information Communication Technology age which embraces all aspect of educational processes, strategies, and activities designed to achieve excellence in education. According to Spector (2008), Educational Technology is viewed as a rational problem solving approach where the opportunities for incorporating business values and self-reliant skills lie at its disposal. Moreover, the programmes in Educational Technology comes out very useful not only for the salaried jobs beneficiaries but more so for self-employment based on skill acquisition with minimal capital requirement.

With the increasing emphasis on $21^{\text {st }}$ Century skills and workforce development for self-reliance, educational technology specialist have put in place innovative ways of using new generation audiovisual technologies such as live broadcast satellite, video conferencing, narrowcast television, hypermedia, multimedia, interactive television instruction, videotaped instruction, video discs, computer disc's, interactive radio, digital technology, portable FM radio, web television, non-linear desktop video and audio-editing system to achieve the goals of educational 
technology.

Educational Technology as a discipline has exposed students to a wide variety of ICT technological tools that can be used to create wealth as well as make students self-reliant. Self-reliance is synonymous with self-sufficiency. It is the ability of a person to identify, harness and manage effectively and efficiently the resources, human or material in the immediate environment in order to uplift one.

For functional education to be achieved in the teaching and learning of educational technology and to bring the reality of self-reliance, emphasis should be lad on developing entrepreneurial skills of educational technology students. Entrepreneurship is best understood as competency or resourceful skills capable of steering an individual to be self-reliant, independent and productive. They are also skills and competences that enable people seek and run enterprises successfully thereby enabling individuals to maximize the resources around him within the limit of his capability (Achufus, Ume, and Okoye, 2009). The skills required of an entrepreneur involve technical skills, human relation skills, creativity skills, problem solving skills and communication skills. These skills are learned through experience, failures and successes in order to arrive at successful ventures.

To acquire entrepreneurial skills, students must utilize educational technology tools in order to demonstrate technological proficiency early in their school year experience. Harris (2000) noted that there is a growing acceptance among academics that the utilization of educational technology tools enables students to create jobs for themselves since the profession clearly describes what students should know and be able to do with technology so as to live a self-reliant life. Educational technology is endowed with new ventures, innovative ideas and opportunities that can encourage students to start their own businesses upon graduation as well as develop graduates who can be skilful with the knowledge gained thus taking responsibility for their own destinies.

Fayomi (2007) stated that business opportunities can arise when educational technology students use their skills, expertise or aptitude to provide a product or service to the market. Similarly, solving existing problems like video editing, graphic design, animation, development of educational materials, supplies, equipment and services, educational training and services, multimedia design, development of educational games, could all become opportunities to start a business. All these among others are available for students of educational technology for self-employment and to be employers of labour (Nsofor, Umeh, Ahmed and Idris (2014).

One of the most successful educational technology tools that can be used for wealth creation is blogging. Blogging is an electronic platform where writers or group of writers share their discussion, information, views as well as make comments on various topics for public discourse. It is also a database containing text entries and other forms of content including pictures and sound files which can be created, edited and published to the web in a flexible manner (Flatley,2005).

Elison and $\mathrm{Wu}$ (2008) opined that blogging encourages critical and analytical thinking as it allows students to develop wider perspectives by interacting with peers and even with a wider audience on the world wide web. Innovative, low cost and flexible approaches to education links the gap between theory and practice which are needed among educational technology students in Nigeria. Thus blogging is a useful tool used to support students with diverse knowledge for real world experience in relation to entrepreneurship. The demand for online blogging is increasing in Nigeria because most students have realized that blogging is an effective technological tool that can enhance entrepreneurship which is constantly shaping and re-shaping the work place as well as the business environment (Azuka, Kanu and Agomuo, 2006).

According to Alam (2009), Blogging has opened global job market where educational technology students upon graduation can do jobs sitting in their own house anywhere in the world. This means that education is the key agent of technology development which has the power to develop human capacity, increased modernization and enable environmental development and empowerment.

Educational Technology resources when utilized by students will help them to be productive members of the society. It can also enhance students work orientation and make transition from school to the world of work relatively easy. Educational Technology has yielded several new machines, materials, media, men and methods which have great potential for use in the business world and if judiciously utilized can bring about lots of opportunities for students (Aggarwal, 2008).

There are several blogging platforms educational technology students can utilize for entrepreneurial purposes. They include wordpress.org (self-hosted), word press.org (online), blogger, freelancer, steemit, medium, ghost, square space among others. These platforms provide asynchronous and synchronous collaboration which offers online feedback and discussion features. They have the potential to promote the development of a business community outside the classroom. 
For instance, Word press. Org is a blogging platform where free open source management system where the software is installed on a web server. It is often called word press-self hosted because one needs to find your own hosting provider and acquire a domain to install your own wordpress site.

Blogger is another blogging platform that is designed for ease because it is owned by google. Users can link it to various google products like photo sharing site and social network sites. Blogger makes it extremely easy for would-be writers to publish their thoughts on the internet. Technically one can earn money from blogger without buying a domain name.

Steemit platform comes from the block chain mining when users post contents on the steemit network. Steemit users are rewarded for content curation and creation. Steemit has three currencies - Steem, Steel power and Steem dollars. It is a blogging platform that allows users to earn currency by simply posting contents. When readers visit a blog site, the HTML code you post on your blog from Google activates and relevant ads like CPS (Cost per Click) displays based on each page's content. Google Ad sense typically pays based on the Click-thru-rate. Each time a reader clicks on the ad, you are paid for the click. Although University students learn about the great potentials blogging platforms can offer in teaching and learning, there is still a huge gap on how these platforms can be used to create wealth far beyond the conventional knowledge of blogging.

Banker, 2003 assert that $75 \%$ of educational technology students are adequately aware of different E-blogs platforms but it's utilization for entrepreneurship is at a low ebb. They lack a lot of knowledge, business experience and different entrepreneurial skills available on the web. Students' awareness of blogging platforms for entrepreneurship is low. Bloggers of different ages and backgrounds tend to use blogging platforms like as a social planning tool where they establish a network of online friends, share their opinions and stories for the public by entertaining themselves rather than utilize it for business purposes. (Scacetta,2006).

Research studies have revealed that there's huge dissatisfaction among educational technology students who upon graduation cannot manipulate basic educational technology tools especially those recruited by local, multinational and private companies. This may be connected with the observation that educational technology resources are not practically utilized during teaching and learning in our colleges of education and universities and that students' exposure to the theoretical aspect of educational technology is alarming while its utilization is discouraging (Nwobas, 2011).

Kenning (2007) posits that Blogs are a potentially valuable tool for entrepreneurship. Their capacity for allowing users to publish and share their views quickly and easily opens a number of possibilities for students and if its utilization is low in a day to day classroom setting, how then can students perform effectively in the global world. Although the introduction of blogs is quite new, the phenomenon has been recognized as a key factor in economic growth of any nation.

\subsection{Theoretical Framework}

This research is anchored on the Theory of Connectivism by George Siemens (2005). According to connectivism, knowledge is distributed to an information network and can be stored in a variety of digital format where individuals learn and work in a networked environment. This environment include virtual meeting spaces like social networking sites such as email, twitter, whatassap, blogs and chat sessions. These learning communities operate regardless of place and offer interesting information about e-learning. The capacity to form connections between sources of information and create useful information pattern is required to learn in the radically changing world of digitalized knowledge economy and globalization.

The underlining idea in connectivism is that learning is cyclical in that learners will connect to a network, to share and find new information that will modify their beliefs on the basis of new learning, and will connect to a network to share new realizations and find new information once more.

\subsection{Statement of The Problem}

Blogging platforms have been effectively taught in the field of educational technology as tools that can enhance teaching and learning however, the application of blogs appears to have great potential far beyond the classroom. Interestingly blogging is not limited to improving teaching and learning processes, it is also a tool for wealth creation that can help an educational technology student become self-reliant.

However, most students despite their awareness of a huge array of blogging platforms such as wordpress.org, blogger, freelancer, ghost, squarespace, steemit, medium among others rarely utilize these platforms for business purposes as blogs is one successful entrepreneurial story students can utilize to create wealth thus yielding tremendous result. 
To acquire employable skills, much effort has to be made by educational technology students in university of calabar to utilize blogging platforms for entrepreneurship so as to make them self-reliant hence the need to fill this gap.

It is against this backdrop that this research is carried out to determine the Utilization of Blogging platforms and Acquisition of entrepreneurial skills for Self-reliance among Educational Technology students in University of Calabar.

\subsection{Purpose of Study}

This study was guided by the following objectives:

a. To examine how Utilization of WordPress. Org platform relates with Acquisition of Entrepreneurial Skills for Self-reliance among Educational Technology students' in University of Calabar.

b. To examine how Utilization of Blogger platform relates with Acquisition of entrepreneurial skills for selfreliance among educational technology students' in University of Calabar.

c. To examine how Utilization of Steemit platform relates with Acquisition of Entrepreneurial Skills for Self-reliance among Educational Technology Students' in University of Calabar.

\subsection{Research Questions}

a. How does the Utilization of WordPress.Org platform relates with the Acquisition of Entrepreneurial Skills among educational technology Students' in University of Calabar for Self-reliance?

b. How does the Utilization of Blogger platform does relates with the Acquisition of Entrepreneurial Skills among Educational Technology Students' in University of Calabar for Self-reliance?

c. How does the Utilization of Steemit platform relates with the Acquisition of Entrepreneurial Skills among Educational Technology Students' in University of Calabar for Self-reliance?

\subsection{Research Hypotheses}

a. There is no significant relationship between the Utilization of WordPress.Org platform and Acquisition of Entrepreneurial Skills among Educational Technology students' in University of Calabar for selfreliance

b. The Utilization of Blogger platform does not relate with the Acquisition of Entrepreneurial Skills among Educational Technology Students' in University of Calabar for Self-reliance.

c. There is no significant relationship between the utilization of Steemit platform and Acquisition of Entrepreneurial Skills among Educational Technology students in University of Calabar for Self-reliance.

\section{Method}

The study adopted the Survey Research Design. Three research questions and three research hypotheses were developed to guide the study. The targeted population of the study consisted of all 39 final year Educational Technology students in University of Calabar. Thirty-nine final year Educational Technology students were purposively adopted as sample size for the study. The instrument for data collection was the Utilization of blogging for Entrepreneurship and Self-reliance Questionnaire (UEESQ). The instrument was divided into two sectionssection A measures 'blogging platforms for Entrepreneurship, while section B Measures Students Utilization of blogging for Entrepreneurship and Self-reliance. The instrument was used after being validated by experts and Chronbach Alpha Reliability Coefficient of .80 was used to test for reliability. Linear regression was used to test the hypotheses at 0.05 level of significance while the model summary table was used to answer research questions.

\section{Results}

\subsection{Research Question 1}

How does the Utilization of WordPress.Org platform relates with the Acquisition of Entrepreneurial Skills among educational technology Students' in University of Calabar for Self-reliance?

Table 1. Linear Regression Model Summary Result on the Relationship between WordPress.Org platform and Entrepreneurial Skills

\begin{tabular}{llccc}
\hline Model & $\mathrm{R}$ & R Square & Adjusted R Square & Std. Error of the Estimate \\
\hline 1 & $.286^{\mathrm{a}}$ & .082 & .057 & .41456 \\
\hline
\end{tabular}


a. Predictors: (Constant), Word Press Org platform

b. Dependent Variable: Acquisition of entrepreneurial skills

\subsection{Research Question 2}

How the Utilization of Blogger platform does relate with the Acquisition of Entrepreneurial Skills among Educational Technology Students' in University of Calabar for Self-reliance?

Table 2. Linear Regression Model Summary Result on the Relationship between Word press.Org platform and Entrepreneurial Skills

\begin{tabular}{ccccc}
\hline Model & $\mathrm{R}$ & R Square & Adjusted R Square & Std. Error of the Estimate \\
\hline 1 & $.253^{\mathrm{a}}$ & .064 & .039 & .44692 \\
\hline
\end{tabular}

a. Predictors: (Constant), Blogger platform

b. Dependent Variable: Acquisition of entrepreneurial skills

\subsection{Research Question 3}

How the Utilization of Steemit platform does relate with the Acquisition of Entrepreneurial Skills among Educational Technology Students' in University of Calabar for Self-reliance?

Table 3. Linear Regression Model Summary Result on the Relationship between Steemit platform and Entrepreneurial Skills

\begin{tabular}{llccc}
\hline Model & $\mathrm{R}$ & R Square & Adjusted R Square & Std. Error of the Estimate \\
\hline 1 & $.157^{\mathrm{a}}$ & .025 & .002 & .48641
\end{tabular}

a. Predictors: (Constant), Steemit platform

b. Dependent Variable: Acquisition of entrepreneurial skills

\subsection{Hypothesis 1}

There is no significant relationship between the Utilization of WordPress.Org platform and Acquisition of Entrepreneurial Skills. among Educational Technology students' in University of Calabar for self-reliance.

Table 4. The Result of Regression on the relationship between the Utilization of WordPress.Org platform and Acquisition of Entrepreneurial Skill

\begin{tabular}{lllllll}
\hline Model & & Sum of Squares & df & Mean Square & F & Sig. \\
\hline 1 & Regression & .564 & 1 & .564 & 3.284 & $.078^{\mathrm{b}}$ \\
& Residual & 6.359 & 37 & .172 & & \\
& Total & 6.923 & 38 & & & \\
\hline
\end{tabular}
a. Dependent Variable: Acquisition of entrepreneurial skills
b. Predictors: (Constant), WordPress.Org

\subsection{Hypothesis 2}

How the Utilization of Blogger platform does does relate with the Acquisition of Entrepreneurial Skills among Educational Technology Students' in University of Calabar for Self-reliance? 
Table 5. The Result of Regression on the relationship between the Utilization of WordPress.Org platform and Acquisition of Entrepreneurial Skill

\begin{tabular}{|c|c|c|c|c|c|c|}
\hline Model & & Sum of Squares & df & Mean Square & $\mathrm{F}$ & Sig. \\
\hline \multirow[t]{3}{*}{1} & Regression & .507 & 1 & .507 & 2.539 & $.120^{\mathrm{b}}$ \\
\hline & Residual & 7.390 & 37 & .200 & & \\
\hline & Total & 7.897 & 38 & & & \\
\hline \multicolumn{7}{|c|}{ a. Dependent Variable: Acquisition of entrepreneurial skills } \\
\hline \multicolumn{7}{|c|}{ b. Predictors: (Constant), Blogger platform } \\
\hline
\end{tabular}

Table 5 shows the Result of Regression on the relationship between the Utilization of Blogger platform and Acquisition of Entrepreneurial Skills with the F-value (2.539) and p-value (.120). Since p $>0.05$, the null is retained. It can therefore be concluded that there is no significant relationship between the Utilization of Blogger platform and Acquisition of Entrepreneurial Skills among Educational Technology students' in University of Calabar for self-reliance.

\subsection{Hypothesis 3}

How the Utilization of Steemit platform does does relate with the Acquisition of Entrepreneurial Skills among Educational Technology Students' in University of Calabar for Self-reliance?

Table 5. The Result of Regression on the relationship between the Utilization of WordPress.Org platform and Acquisition of Entrepreneurial Skill

\begin{tabular}{lllllll}
\hline Model & & Sum of Squares & df & Mean Square & F & Sig. \\
\hline 1 & Regression & .220 & 1 & .220 & .932 & $.341^{\mathrm{b}}$ \\
& Residual & 8.754 & 37 & .237 & & \\
& Total & 8.974 & 38 & & & \\
a. Dependent Variable: Acquisition of entrepreneurial skills & & \\
b. Predictors: (Constant), Steemit platform
\end{tabular}

Table 6 shows the Result of Regression on the relationship between the Utilization of Steemit platform and Acquisition of Entrepreneurial Skills with the F-value (.932) and p-value (.341). Since p >0.05, the null is retained. It can therefore be concluded that there is no significant relationship between the Utilization of Steemit platform and Acquisition of Entrepreneurial Skills among Educational Technology students' in University of Calabar for self-reliance.

\section{Discussion}

Table 1 shows the result on the Relationship between WordPress.Org platform and entrepreneurial skills among educational technology students' in University of Calabar for self-reliance. The table reveals the correlation coefficient as .286 and a coefficient of determination $\left(\mathrm{R}^{2}\right)$ as 082 . This implies that a weak relationship exists and that variation in acquisition of entrepreneurial skills among educational technology Students is explained by .082\% of Word press. Org platform. Generally, the result indicates that Educational Technology Students do not utilize Wordpress. Org Platform for entrepreneurship.

Table 2 shows the result on the relationship between blogger platform and entrepreneurial skills among educational technology Students' in University of Calabar for self-reliance. The table reveals the correlation coefficient as .253 and a coefficient of determination $\left(\mathrm{R}^{2}\right)$ as .064 . This implies that a weak relationship exists and that variation in acquisition of entrepreneurial skills among educational technology Students is explained by $.064 \%$ of Blogger platform. Generally, the result indicates that Educational Technology Students do not utilize blogger Platform for entrepreneurship.

Table 3 shows the Result on the Relationship between Steemit platform and Entrepreneurial Skills among 
educational technology Students' in University of Calabar for Self-reliance. The table reveals the correlation coefficient as .157 and a coefficient of determination $\left(\mathrm{R}^{2}\right)$ as .025 . This implies that a weak relationship exists and that variation in acquisition of entrepreneurial skills among educational technology students is explained by $0.25 \%$ of Steemit platform. Generally, the result indicates that Educational Technology Students do not utilize steemit platform for entrepreneurship.

Table 4 shows the Result of Regression on the relationship between the Utilization of WordPress.Org platform and Acquisition of Entrepreneurial Skills with the F-value (3.284) and p-value (.078). Since p $>0.05$, the null is retained. It can therefore be concluded that there is no significant relationship between the Utilization of Word press. Org platform and Acquisition of Entrepreneurial Skills among Educational Technology students' in University of Calabar for self-reliance.

Hypothesis one reveals that there is no significant relationship between the Utilization of WordPress.Org platform and Acquisition of Entrepreneurial Skills among Educational Technology students' in University of Calabar for self-reliance. This implies that the utilization among Educational Technology students' is very weak that it does not enhance Acquisition of Entrepreneurial Skills. This finding is supported by the finding of Fayom (2007) stated that business opportunities can arise when educational technology students use their skills, expertise or aptitude to provide a product or service to the market.

Hypothesis two reveals that there is no significant relationship between the Utilization of Blogger platform and Acquisition of Entrepreneurial Skills among Educational Technology students' in University of Calabar for selfreliance. This implies that utilization of Blogger platform is weak among educational technology students. This finding is supported by the finding of Kenning (2007) posits that Blogs are a potentially valuable tool for entrepreneurship. Their capacity for allowing users to publish and share their views quickly and easily opens a number of possibilities for students and if its utilization is low in a day to day classroom setting, how then can students perform effectively in the global world.

Hypothesis three reveals that there is no significant relationship between the Utilization of steemit platform and Acquisition of Entrepreneurial Skills among Educational Technology students' in University of Calabar for selfreliance. This implies that the usage is very low hence does not encourage acquisition of Entrepreneurial Skills. This finding is supported by the finding of (Aggarwal, 2008) who opined Educational Technology has yielded several new machines, materials, media, men and methods which have great potential for use in the business world and if judiciously utilized can bring about lots of opportunities for students.

\section{Conclusion}

The importance of creativity and innovation through entrepreneurship and educational technology has been recognized as panacea for unemployment among educational technology students. Nigeria's innovative capacity and the development of a creative and knowledge-intensive economy and society can be achieved through reinforcing the role and training of educational technology graduates in the knowledge triangle and focusing course curricula on creativity, innovation and entrepreneurship which will in turn bring about self-reliance.

\section{Recommendations}

Emphasis should be laid on entrepreneurial skills and educational technology tools such as design, production and modernization of indigenous resources among students through practices and innovations for achieving self-reliant generation.

a. The federal government should establish a sustainable national exhibition for educational technology students to stimulate the production of high quality materials that can make them self-reliant.

b. Curriculum developers should integrate entrepreneurial aspect of all levels of educational technology curriculum by promoting learning by discovery method, experiential learning through interactive environment, promoting attitudes to self-reliance among educational technology students.

c. Educational Technology instructors should introduce an intensive mentoring program by building alliances and relationships with other entrepreneurs and business professionals so as to gain personal insights, develop concepts and formulate new ideas with this form of training.

\section{References}

Achufus, J. N., Ume, N. O., \& Okoye, E. (2009). Assessment of resources for developing entrepreneurial skills through science, technology and mathematics education in secondary schools. 50th Annual Proceedings of Science Teachers Association of Nigeria, pp 100-105.

Aggarwal, J. C. (2008). Essentials of educational technology, innovations in teaching-learning (2nd Ed.). New 
Delhi: Vikas Publishing House PVT Ltd.

Alam, G. M. (2009). The role of science and technology education at network age population for sustainable development in Bangladesh through human resource advancement. Scientific Research and Essay, 4(11), 1260-1270. Retrieved

from https://pdfs.semanticscholar.org/dfbd/b129618b19b7082d3383c45612178027bfd4.pdf.

Ayo, C. K. (2001). Information technology, trends and applications in science and business. Lagos: Concepts Publications.

Azuka, E. B., Nwosu, B. O., Kanu I. N., \& Agomuo E. E. (2006). Foundation of business education in Nigeria. Oko, Anambra: Data-World Publications, p. 226.

Banker, R. (2003). Returns on investment in information technology. Paper Presented at the International Intellectual Capital Conference, Taipei, 24-27 April.

Elison, N. B., \& Wu, Y. (2008). Blogging in the classroom: A preliminary exploration of student attitudes and impact on comprehension. Journal of Educational Multimedia and Hypermedia, 17(1), 99-122. Retrieved from http://homepages.utoledo.edu/jlamber4/5550/blogging.pdf.

Fayomi, S. B. (2007). Entrepreneurship education for employment opportunity awareness creation among undergraduates of Obafemi Awolowo University Ife. Journal of Educational Studies, 13(1), 57-65.

Flatley, M. E. (2005). Blogging for enhanced teaching and learning. Business Communication Quarterly, 68(1), 77-80.

Harris, P. (2000). Using technology to create a new paradigm for a teacher-centered educational experience. Technos Quaterly, 9(2), 21-32. Retrieved from http:/www.technosnet/tq-09/2harris.htm

Kenning, M. M. (2007). ICT and language learning from print to the mobile phone. New York: Palgrave Macmillian. https://doi.org/10.1057/9780230591325.

Nsofor, C. C., Umeh, A. E., Ahmed, B., \& Idris, A. W. (2014). Creating self-reliant opportunities through entrepreneurial and functional educational technology: Panacea for Nigeria's youth unemployment. Journal of Educational Practice, 5(35), 30-35.

Nwobasi, P. A. (2011). The roles of technology and vocational education in enhancing entrepreneurial skills in a global economy. Retrieved from www.stanonline.org/journal/pdf/JSTAN-Paul\%202011.

Ololuybe, N. P. (2006). Appraising the relationship between ICT usage and integration and the standard of teacher education programmes in a developing economy. International Journal of Education and Development, 2(3), 194-212.

Scaletta, K. R. (2006). To whom are these texts valuable? An inquiry into student blogging' master's project, University of Minnesota. Retrieved from www.inms.umn.edu/events/past/newresearch_2006/scalletta.html.

Siemens, G. (2005). Connectivism: A learning theory for the digital age. International Journal of Instructional Technology and Distance Learning, 2(1), 3-10. http:/www.itdl.org/Journal/Jan_05/article01.htm.

Spector, J. M., Merrill, M. D., \& Drosscoll, M. P. (2008). Handbook of research and educational communication and technology (3rd ed). Mahwah NJ, Lawrence Erlbaum Associates Publishers, p. 928.

Yusuf, M. O. (2005). Integrating ICTs in Nigeria tertiary education. The African symposium. An Online Journal of Educational Research Networks, 5(2), 43-55.

\section{Copyrights}

Copyright for this article is retained by the author(s), with first publication rights granted to the journal.

This is an open-access article distributed under the terms and conditions of the Creative Commons Attribution license (http://creativecommons.org/licenses/by/4.0/). 